\title{
Children's Toys and Memories of Migration in Australian Museums
}

Eureka Henrich

King's College London, Menzies Centre for Australian Studies, Strand, London, WC2R 2LS, UK

A miniature English cottage, a doll's dress made of paper and a 'Game Boy': what could these objects have in common? All are toys that belonged to children who had moved to a new country, and all have been displayed in exhibitions of migration history. From unaccompanied child migrants, to refugee arrivals and children living in immigration detention, these toys and other children's things are often windows onto controversial topics that allow visitors to imagine themselves in someone else's smaller shoes. But what do they tell us about children's differing experiences of migration, and the roles that possessions such as toys play in the remembering and retelling of those experiences? This article draws on examples from three decades of exhibitions in Australia to examine how, and why, children's toys and the memories associated with them have been an important way of engaging audiences in historic and contemporary experiences of migration.

Keywords: Australia, migration, oral history, memory, toys, children

\section{Introduction}

...We are heading to Australia, imagine! So far away, it feels like we are going to the end of the world but I promise that as soon as Pinochet is ousted, the same month I will return to Chile. We have to go to Buenos Aires first, because the Australian Embassy is located there. They will give us visas to enter the country. Apparently we are leaving next Tuesday, only then will they tell us when we will be going to Australia. I wonder how we will cope? What is going to happen to us? (Powerhouse Museum 2004)

When fifteen-year-old Sara and her family fled the horrors of Pinochet's Chile in 1975, they knew little about their destination - Australia - a country that seemed to be located at 'the end of the world'. The sense of adventure combined with uncertainty and anxiety captured in Sara's diary entry gives us a precious insight into a child's experience of migration. ${ }^{1}$ Along with the diary, Sara brought her books and a teddy bear, treasured possessions representing a home that she was determined to return to. Nearly thirty years later, in 2004, Sara's story was featured in an exhibition at the Powerhouse Museum in Sydney called Childhood Memories 
of Migration, her teddy now behind glass for others to look at and ponder (Powerhouse Museum 2004). By that stage, Australian museums had been exhibiting migration history for almost twenty years. One striking feature of these exhibitions has been the frequent display of children's toys, often accompanied by other sources such as diaries and oral histories. Amongst the familiar objects of the migration exhibition, such as the suitcases, travel documents, and letters home, toys have been the primary vehicle through which children's experiences and adults' memories of migration as children are represented to visitors. But this use of toys, the 'archetypal symbols of childhood', carries with it a challenge shared by all who research and seek to represent the historical experiences of children. As Carla Pascoe (2010, 1147) writes, 'because we were all children once, the challenge... is to move beyond the assumption that we intuitively know what it felt like to grow up in past eras and to actively, self-reflexively historicise changing experiences of childhood'. In exhibitions about migration, this challenge is compounded by the need to move beyond the tropes of the migrant journey (McShane 2001) to delineate different historic and contemporary experiences of movement and mobility - from forced migrants, survivors of trauma and war, refugees and unaccompanied child migrants, to children of highly mobile parents who will live in multiple countries and others seeking a new start or a better standard of living. As historians of childhood and their colleagues in archaeology are increasingly turning towards children's material culture to overcome a lack of child-authored sources in the past (Pascoe $2010,1147)$, the frequent use of toys in museum exhibitions of migration offers an important case study in the interpretation of childhood. And Australia, by virtue of its comparatively early introduction of multicultural policies (Lopez 2000, 68), provides the longest continual history of migration exhibitions in the world (Henrich 2013).

Drawing on six exhibitions across five different museums, this article will demonstrate how children's toys and other objects have been an important means to engage audiences in Australia's migration history over three decades. It situates these museum exhibitions within their institutional and historical contexts, from the first migration exhibitions of the 1980 s to the past few years, in order to better understand why curators have used the perspectives of child migrants and the memories of adults who migrated as children. In doing so it acknowledges the dual challenge of presenting the history of migration and the history of children - both marginal historical narratives in which stereotypes and nostalgia can impede the reconstruction of the past. 


\section{Contexts and approaches}

The very nature of museum exhibitions as temporary and ephemeral has resulted in a scholarly focus on the history of institutions and collections, both of which are generally more enduring and better documented. Important anthologies have been published on some of the museums discussed here, but rarely is there enough space in these tomes to address a single exhibition in any depth (Davison and Webber 2005; Rasmussen 2001).There has also been a recent spate of publications which elevate a selection of individual objects from museum collections in order to tell broader narratives about national and world history, but these works pay less attention to how objects have previously been exhibited. ${ }^{2}$ By contrast, the research that this article draws on originated in a doctoral project which argued that it is the exhibition, rather than the collection, which the majority of people will experience when visiting a museum (Henrich 2012). Unlike a film or a book, which can be read or watched again years after its creation, a museum exhibition needs to be 'reimagined'; pieced together like a jigsaw puzzle through the records and memories that remain of its existence. The types of sources that I have drawn on here include design briefs, floor plans, object lists, photographs, education kits and exhibition catalogues. In most cases copies of the final exhibition text and graphics were available in the museum's archives or publishing departments, and other sources such as exhibition reviews, curators' conference papers and (more recently) blogs helped to fill in the picture. Crucially, oral history interviews with past and present curators of the Migration Museum SA, the Immigration Museum in Melbourne, the National Museum of Australia in Canberra and the Australian National Maritime Museum in Sydney enabled me to discover the political and institutional circumstances in which exhibitions were created. These changing contexts shape the way histories of migration are presented, and, as we will see, the way that children's perspectives and objects are used to tell those histories.

In thinking about museum exhibitions from the perspective of the historiography of childhood, there are a number of internationally comparative examples on which to draw. Sharon Brookshaw's research $(2006,156)$ on representations of children and childhood in British museums revealed that although the literature assumes an under-representation of children, the majority of institutions surveyed recognised objects in their collections that relate directly to the children's experiences. When investigating the use of these objects in exhibitions, Brookshaw found three recurring narratives. Nostalgic presentations of idyllic 
childhoods were often characterised by toys, especially rocking horses, teddy bears and dolls - objects representing comfortable middle class childhoods which tell us little of the experiences of children themselves. Conversely, other displays presented the "child as victim', an innocent corrupted by the adult world. Recent research by Simon Sleight (2013, 126-43) on the representation of child workers in museum exhibitions in the United States, Australia and Britain confirms the continued prevalence of this trope. A third image Brookshaw identified represents a middle ground - the 'ordinary child', neither privileged nor condemned. Interestingly, these more balanced and historically-nuanced displays tended to result from a focus on place, or 'geographically bound childhood', and included experiences of work, poverty and poor health whilst acknowledging the pleasures of play enjoyed by working-class and wealthy children alike. As Brookshaw (2006, 159-160) notes, this transition from a nostalgic ersatz view of childhood to the assertion of children's exploitation, and finally a reassessment of both views and an acknowledgement of young people's agency, reflects the development of the historiography of children and childhood.

More recently, an edited collection on Children, Childhood and Cultural Heritage has drawn together work on the creation, collection, interpretation and display of children's cultural heritage. Extending the purview of children's things to encompass the intangible world of games, rhymes, stories and song, the contributors demonstrate how attention to cultural heritage can reveal changing attitudes of and to children, as well as the constancy of particular types of play across generations and countries. As Gwenda Beed Davey, Kate Darian-Smith and Carla Pascoe note in their chapter on playlore, these types of heritage have recently found their way into museum exhibitions $(2013,43){ }^{3}$ They cite the 2011 exhibition 'Identity: yours, mine, ours' at Melbourne's Immigration Museum, where children's songs and rhymes were used to explore racism and perceptions of difference in children's culture. In a separate chapter Pascoe $(2013,209-221)$ historicises museums of childhood and children's museums in the United Kingdom, United States, Canada and New Zealand, unpicking the oft-times blurred distinction between the two types of institutions and the enduring challenge presented by the adult production of sources about and for children (for example, toys and child-rearing guides).

The relative infancy of scholarship on representations of children in museums is reflected in Children, Childhood and Cultural Heritage by reliance on recent exhibitions, and on specialist museums of children and childhood. Important questions remain about how children have been represented in other types of museums, especially given the increasinglysignificant role of museums as places of learning, with schools often providing the 
predominant visitor group (Griffin 2011, para 2). Additionally, different types of museums (and visitor expectations of those museums) frame children's material culture in different ways - a teddy bear may take on new meanings when exhibited in a holocaust museum, a museum of science and technology, a national museum or a migration museum.

The institutions examined here are a combination of state (Immigration Museum, Powerhouse Museum and Migration Museum SA) and federally-funded museums (National Museum of Australia, Australian National Maritime Museum). They were opened or rejuvenated as part of a renaissance in Australian cultural institutions that began in the late 1970 s, spurred on by the entry of historians into museums, the embrace of social history themes and narrative-style exhibitions designed to appeal to a domestic audience increasingly interested in their nation's past (Anderson 2011, para 4; Trinca 2013, 140-141). But by the early 2000 s, these publicly-funded museums found themselves embroiled in what has become known as Australia's 'history wars', where historiographical debate exploded into oppositional polemics, fuelled by media speculation and hijacked by politicians furthering their own agendas (Clark 2013, 151-166). While these broader intellectual and political contexts cannot be adequately explored here, it is important to note that Australian museums have been reluctant conductors for the heat in these debates about the nation's past. The arrival of particular types of migrants, such as colonists in the $18^{\text {th }}$ century and asylum seekers in the late $20^{\text {th }}$ and early $21^{\text {st }}$ centuries, has at times placed exhibitions of migration history in the firing line of these domestic battles. The representation of children in these exhibitions has until now, never been examined in isolation. Pascoe $(2013,210)$ points out that 'our understandings of children in the present as innocent, carefree, vulnerable and dependent have profound implications for how we view children in the past'. In this article I suggest that by examining museum exhibitions of migration history in Australia over a number of decades, we can begin to see how different 'presents' have produced different pasts, and how museum-workers have responded to changing social and political contexts to tell stories of children's migration.

\section{'Chapters in Childhood: Glimpses into the history of childhood in South Australia', Migration Museum SA, 1987-1988}

I wanted to do [an exhibition] about children, partly because I thought it was a very non-threatening way to talk about the history of immigration, people were quite 
prepared to talk about their far past where as they sometimes weren't prepared to talk about their near past (Szekeres 2009).

In 1986 the world's first museum of migration history opened in Adelaide, in the state of South Australia. Initially seen by the state government as an opportunity to acknowledge and celebrate different 'ethnic communities', in line with recent multicultural initiatives, the curatorial staff and working party made up of representatives from different migrant groups instead created a museum about the history of migration and settlement. In their view an 'ethnic museum' would only entrench views about migrants being 'different'. The opening permanent exhibitions wove a chronological narrative of immigration to South Australia from the first British colonists to recent refugee arrivals, acknowledging that for Indigenous Australians, migration was a symptom of invasion and dispossession. A community gallery called the Forum provided a space for organised groups to mount their own exhibitions, and temporary galleries hosted a series of displays about important ethnic minorities, such as German South Australians. But as the then-director, Viv Szekeres, remembers, museum staff were increasingly looking for ways to explore the complex and layered nature of culture and identity, beyond the limitations of ethnicity or nationality. 'Chapters in Childhood' became the first of a series of cross-cultural thematic exhibitions that inter-wove the stories of different migrant individuals and groups from a range of backgrounds. It was born of expediency: without much time for exhibition development, Szekeres drew on her background as a lecturer in the history of childhood, and on the history of the building the museum was located in - a former Destitute Asylum for single women and their children. An oral history project called 'SA Speaks' had collated interviews of adult migrants by museum staff and, as Szekeres noted (1987, 112-116), they often wanted to talk about their childhoods - some even offered objects for the exhibition. Other objects were borrowed from the Children's Library of the State Library of South Australia, including a toy tea set, a tail-less donkey game, and a set of skittles. ${ }^{4}$ Szekeres later described the exhibition as 'a display about the different experiences a child might have in different cultures and at different times' (Szekeres, 1988).

So how did curators represent the historical experiences of children, and the memories of contemporary South Australians? The exhibition was split into two sections - the first dominated by a toy shop window installation displaying a wide variety of play objects, including German, Chinese, Russian, Scottish and Australian-made dolls, toy train engines, 
games, music boxes, lanterns, picture books, puzzles, and sports equipment. Objects were not associated with individual children, and in that sense appeared generic, almost like a toy museum. The surrounding text panels told a history of childhood in South Australia, including sections on children-as-workers, Aboriginal children and children-as-migrants. Accompanied by photographs, such as European children playing at migrant hostels in the 1940s and 1950s, this display highlighted the diversity of children's experiences: 'some were refugees escaping from their own countries because of war; some came alone; others came with their parents in search of new opportunities' (Migration Museum SA 1987).

The second section consisted of eight giant books, taller than the average visitor, whose pages could be turned to reveal the stories of South Australians from different cultures, most of whom had migrated to the state as young children (some had grown up there in migrant families). Each story contained a map of their country of origin, family photographs, and a narrative of their childhood constructed from oral history interviews. Like the earlier section, curators were careful to choose a diversity of childhood experiences. Some grew up in rural areas, others in bustling cities. Some children worked or did chores, others were more privileged and only had to study. Class and gender, as well as ethnicity, were important differentials between the featured stories, although all the subjects shared a non-Anglo heritage and spoke a language other than English. Interviewees were asked, 'What made your childhood special?' Their responses included stories told to them by their parents, religious and family celebrations, traditional foods cooked at special times, household chores and experiences of school. Ruth, who was born in Estonia in 1928 and grew up on a farm, had to leave home following the Russian invasion of 1940. Although it was a 'very turbulent time', she said 'I wouldn't change a day of my childhood', a time she remembered fondly. Lorna, who arrived in Australia 1922 from Lebanon, recalled how she felt when she brought her Australian friends home: 'We used to hate Mum and Dad speaking in Arabic in front of them. We'd give them a kick under the table'. Years later Lorna's daughter was the first nonAnglo-Celtic girl to attend a Church of England School in Adelaide, and remembered being called 'dago' by her classmates. ${ }^{5}$ Overall, experiences of those represented were positive, perhaps because of their very willingness to share those memories, rather than others.

One noticeable absence was the perspective of contemporary child migrants - many children who visited the exhibition would have been children of migrants or migrants themselves. By 1988, one in five Australians was born overseas, making Australia second only to Israel as the world's 'most immigrant nation' (Richards 2008, 270). But by presenting childhood as something historical, the display appealed to the nostalgia of older visitors and 
to school groups learning about childhood in the past. That 'past-ness' was encapsulated by the display of old-fashioned toys, all long since abandoned as play objects.

\section{'Tears, Fears and Cheers: Migration to Australia, 1788 - 1998', Australian National Maritime Museum and 'Leavings', Immigration Museum, Melbourne, 1998.}

By the late 1990s the range of Australian museums exhibiting migration history had diversified to include the Australian National Maritime Museum in Sydney (opened in 1991) and the Immigration Museum in Melbourne (opened as a new campus of Museum Victoria in 1998). ${ }^{6}$ In this section I want to consider two exhibitions from these museums that were both unveiled in 1998: a time when debate over migration and multiculturalism had reached a peak in Australian public culture. Two concurrent anxieties fuelled this debate - a concern that increased rates of Asian migration were undermining the cultural cohesiveness of Australian society, and hysteria over the 'illegal' arrival of asylum seekers by boat (Pickering 2001, 171172). While such concerns had surfaced periodically throughout the previous decades, in the mid-1990s they gained new legitimacy through the combined effects of an economic recession, the election of a conservative federal government, and the election to parliament of an independent Queensland politician named Pauline Hanson (Economou 2007, 43). Hanson notoriously declared that Australia was in danger of being 'swamped by Asians'. She formed her own political party, 'One Nation', in 1997, on a platform of abolishing multiculturalism and halting immigration not directly tied to investment.

The Australian National Maritime Museum opened the temporary exhibition 'Tears, Fears and Cheers: Migration to Australia 1788 - 1998' in the midst of this debate, and promoted the exhibition through posters emblazoned with the words 'Migration: Get the Facts'. Curators wanted to cut through the media hype surrounding Hanson's vitriolic views and instead suggested that migration has been a feature of 'mainstream Australian history' since British colonisation, not a new 'un-Australian' aberration (Jones 1999). The first section, 'Profiles of Australia', used graphs and statistics to explore the changing migrant intake. The second section, 'Ships that Shaped Australia', introduced the main phases of Australian migration history through recreations. Here, children's experiences were presented in a number of ways. For the post-Second World War era, a migrant hostel bedroom and kindergarten classroom highlighted the dominant experience of migrants - living for weeks, months or even years in government-provided accommodation, often in corrugated iron ex- 
army Nissen huts. The classroom evoked childhoods spent in a strange place, making new friends and learning English (which was portrayed as the key to successful assimilation, the government policy for migrants at the time) (Trepa 1997). Contemporary migrant children were featured in one of the short films made for the exhibition, called 'Playing Together'. Curator Kevin Jones noted that these films were designed to broach sensitive topics that had become overtly politicized in the media (Jones 2009). The primary-school-aged children in the video were asked by a bubbly teenage host about the differences between Australia and the countries they came from. One girl described her experience in Serbia: 'in the middle of school, the bombs come'. A Somalian child said 'Mum took me and my sister but they killed my Dad and they killed my brother. After that I wasn't hungry'. One Yugoslavian girl described her old school: "if you do something, anything wrong, they get a big stick and they just put it on your hand, just hitting' (Henrich 2012, 256). Finally, a recreation of the wheelhouse of $T u D o$, a refugee boat disguised as a fishing vessel and used by the Lu family to escape war in Vietnam in 1977, featured a small collection of plastic toys. The pink dog with green wheels, tiny pink doll and toy trumpet had been bought by curator, Helen Trepa, and $T u$ Do's captain and builder, Tan Lu, on a trip to Vietnam to acquire objects for the exhibition (little had survived to document their original voyage). The decision to purchase toys to represent refugee children's experiences of migration is highly significant. It highlights the challenge that migration museums face in exhibiting the stories of refugees, who often arrive with little in terms of material culture; but also reflects the difficulties in exhibiting the experiences of children, whose playthings are often ephemeral rather than precious (Henrich 2011, 79-80).

At the Immigration Museum in Melbourne, a thematic (rather than chronological) approach to Victoria's migration history was designed to emphasise the similarities in the migration experience across time and generations, from 'Leaving Home', to 'Settlings', 'Journeys' and 'Impacts'. In the 'Leaving Home' gallery, migrants' motivations for leaving their homelands were explored. One case, called 'Toys and Memories', displayed two dolls, some paper dolls' dresses, a miniature Nissen hut and a Game Boy. The explanatory label (McFadzean et. al. 1998) read:

Toys brought by children help maintain a sense of community with their new homeland.

Toys brought by adults evoke precious memories of the past.

Toys sent by grandparents help sustain a child's links to distant loved ones. 
Unlike 'Chapters in Childhood' or 'Tears, Fears and Cheers', this text pointed out that toys have been brought by adults, as well as children, and that the experience of migration can transform the significance of personal belongings. Object labels (McFadzean et. al. 1998) in this display were kept simple and brief, leaving the objects as the focus:

Nissen hut, brought to Australia by an English boy, 1945.

Gaucho doll and costume, sent to Argentinian children in Melbourne by their grandmother, 1960s.

Paper dolls' dresses made in the 1940s by an Italian child, even though her parents were too poor to buy her a doll.

Doll, brought from Bavaria, $19^{\text {th }}$ century.

‘Game Boy’ electronic game, 1990s.

The individuals who treasured these toys remain anonymous, united only through the experience of 'leaving home'. The message, similar to that of 'Tears, Fears and Cheers', was one of sameness - no matter how they came, when they came or what they arrived with, all migrants have endured the separation and uncertainty of a long journey to Australia. In the case of 'Tears, Fears and Cheers' though, the perceived innocence of children made their migration experiences especially palatable for museum audiences, given the political context in which those fleeing persecution were increasingly viewed with suspicion and disdain. While political rhetoric de-humanised and criminalised refugees as 'illegals' (Pickering 2001, 173), the 'Playing Together' video exposed the traumatic experiences of child migrants through their own words, as they played in a familiar Australian playground. Likewise, the brightly colored toys used to illustrate the journey of the Lu family disrupted the threatening image of 'boat people' pedaled in the media by replacing it with the image of blameless children, playing with toys to pass the time on a life-altering journey.

'Horizons: The Peopling of Australia since 1788', National Museum of Australia, 2001, and 'On Their Own: Britain's Child Migrants', Australian National Maritime Museum, 2010 
It was a tiny little English house... to remind me of England. I felt if I had something English, there was still that hope (National Museum of Australia 2000).

Examining a history of exhibitions, rather than a history of an institution, can unearth instances where the same object has been exhibited in different contexts. This is the case with a 'tiny little English house', owned by Pamela Smedley, and lent to both the National Museum of Australia and the Australian National Maritime Museum. In this section, rather than analyse two entire exhibitions I want to explore the way this small object was used in different 'presents' to represent one person's past. Pamela was one of approximately 100,000 unaccompanied children who between the 1860s and 1960s were sent from Britain to Canada, Australia, and other Commonwealth countries through various government-sponsored migration schemes (see Bean \& Melville 1989). She arrived in Australia at the age of twelve, and spent her first three years in an orphanage, after which she was sent to work on a sheep station where she cooked and cleaned for shearers. Pamela bought the miniature house with her first pay, to remind her of her home country.

At the National Museum of Australia, which opened in the nation's capital, Canberra, in 2001, Pamela's story was featured in the Horizons exhibition, in a section called 'Coming to work'. As the title suggests, this part of the exhibition explored the concept of migrants-asworkers, skilled people with ambitions to make new lives in Australia. Eight personal stories were chosen, spanning the period from British colonisation in 1788 to the present, and encompassing successful, disappointing, tragic and triumphant experiences. Pamela's story sat uncomfortably with the others. As a child, she had no intention of coming to Australia to work, indeed, she had no say in the matter. While objects such as dentistry equipment, certificates of qualifications and cherished family treasures revealed the professional and familial ties that shaped the other migrants' identities, Pamela's tiny house emphasised her isolation and loneliness. Her story was used to represent a chapter in Australia's migration history that was at that stage little-known, and a nearby panel on child migration explained that hers was one experience among many (Henrich 2012, 290-291).

National inquiries into child migration schemes in Australia and Britain in the late 1990s resulted in a raft of recommendations to right the wrongs of the past, including offering official apologies to former-child migrants (in Australia in 2009 and in Britain the following year), and allocating funds to record and memorialise their experiences (Australian Parliament, 2001; Great Britain, House of Commons 1998). These gestures of communal 
regret and atonement gave important validation to those who had been forcibly removed from their homelands as children, and they also acknowledged the importance of 'bearing witness' to their experiences and memories (Darian-Smith 2013, 167-170). 'On Their Own: Britain's Child Migrants' was a travelling exhibition jointly developed between the Australian National Maritime Museum and National Museums Liverpool against this changing political backdrop. It aimed to 'tell the compelling story of child migration within its global and historical context and within the framework of immigration and child welfare policy' (Tao 2014). Reflecting the personal testimony heard during the national inquiries, oral history was at the heart of the displays and personal stories provided powerful evidence of the life-long impact of forced migration. Pamela's experience was represented in a section called 'The schemes dig in', and again her miniature cottage was the focus object, with the exhibition text explaining how it provided her with comfort and hope. However, in this exhibition there was more space to explain how the little house embodied her longing for a family. Pamela's search for her family was located within the history of organisations such as the Child Migrants Trust, which worked to reunite her with her mother Betty. The deceit and harm that surrounded Pamela's migration added to the poignancy of all that the tiny house represented for forty years, Betty had believed that Pamela had been adopted by a 'loving family' in Britain, whereas Pamela had been told by nuns that her mother had heartlessly abandoned her at birth (Australian National Maritime Museum and National Museums Liverpool 2010).

\section{'Childhood Memories of Migration: Images, Imaginings and Impressions', Powerhouse Museum, 2003-2004}

Sara Bressa, whose diary entry began this article, was one of six adults whose memories featured in the evocatively titled exhibition 'Childhood Memories of Migration: Images, Imaginings and Impressions'. Originally researched and curated at the Fairfield City Museum and Gallery in south-west Sydney in 2003, the exhibition was later mounted in the community gallery of the Powerhouse Museum, a leading museum of social history, design and technology. The origins of the exhibition are important. All of the featured adults were once children at the nearby Villawood and Cabramatta migrant hostels between 1950 and 1990, places that help to explain why the Fairfield area is one of the most culturally and linguistically diverse in Sydney (migrants often settled nearby the hostels when they had earned enough to build their own homes).The focus on memories of 'place' also allowed 
curators to make a direct connection to children who were currently residing in the former Villawood Hostel, which had become an immigration detention centre (Dunn 2010). The introductory panel read:

Children of asylum seekers are now accommodated at the former Villawood Hostel, but with reduced freedoms and facilities. Like the children in this exhibition, the decision to leave their homeland was made for them. What will their memories be? (Powerhouse Museum 2004).

The exhibition was thus able to sensitively engage with an otherwise 'rancorous national debate' (Richards 2008, 330) about asylum seekers by connecting their experiences to those of a previous generation of migrants, who had since settled and become Australians.

Toys, drawings, photographs and other memorabilia belonging to the six subjects were used to explore their different experiences of migration, tracing their stories from 'homeland to hostel to home'. Objects tended to relate to memories of specific places, such as the comic books and cereal packet guns lent by Peter Robinson. Arriving as a ten year old from Ireland in 1951, along with his younger brother and parents, Peter 'entertained himself at Cabramatta Hostel by trading comic books and making toys out of cereal packets from the dining hall'. Common childhood memories of 'foreign and tasteless' food served at the hostels were illustrated by hostel recipe books and a menu, while the exhibition of furnishings that were standard issue complemented memories of domestic family spaces (many remembered using the fold-out divan as a 'bouncy lounge'). Making toys and playthings was also part of the migrants' memories of hostel life, as illustrated in a photograph of a go-cart. The text noted:

Hostels provided the freedom for children to indulge their childhood fantasies. On reflection, most migrant children feel that it was their parents who mainly experienced the uncertainty of creating a new life (Powerhouse Museum 2004).

The exhibition evoked these children's spaces of imagination and play though the memories of adults, memories that were stimulated by objects and photographs they had kept safe. 


\section{Conclusions}

The glimpses into Australia's rich history of migration exhibitions afforded in this article make plain the many and varied ways that children's experiences have been exhibited, and the changing meanings that possessions such as toys take on depending on their immediate contexts - both within the exhibition, and within broader debates concerning migration and culture. Toys have frequently been used as symbols of childhood. They remind us that children have been migrants too, and that migration is a different experience for children and adults. In the toyshop window of 'Chapters in Childhood' the diversity of playthings from different countries and eras also symbolised the diversity of cultures and ethnicities in Australia, reflecting the embrace of multiculturalism amongst museum staff keen to reveal South Australia's long history of migration. However the children who once owned these toys, and their experiences of migration, were not specified, and the display was disconnected to the complex histories displayed in text and images around the walls. By contrast, the plastic toys exhibited in 'Tears, Fears and Cheers' related directly to the 1977 voyage of children aboard the refugee boat $T u D o$, and the fact that the toys had to be purchased to represent others long since lost was an important reminder that the material record of refugee journeys is often fragmented. In this exhibition and others, children's perspectives on the migration experience have been a boon for curators, providing a non-threatening and accessible way to address complex topics such as racism, cultural difference and public perceptions of asylum seekers. But apart from interviews, such as the children interviewed in the 'Playing Together' video, and the occasional display of diaries, letters and drawings, the exhibition of sources that reveal the perspective of children-as-migrants (rather than adult's memories) are hard to come by. A temporary travelling exhibition of drawings created by children whilst they were in an Australian immigration detention centre in remote South Australia, called 'Innocent Victims: Children's Drawings from Woomera', is a rare example, however experiences of detention, rather than migration, were the focus (Goodnow 2008, 4546).

In the 'Memories and Toys' section of 'Leaving Home', and the Pamela Smedley section of 'On Their Own', an explicit link was made between the children's toys on display, and their importance to the memories and identities of the adults who treasured them. Oral histories with adults who migrated as children are invaluable to understanding how those migrations have shaped their lives, but they can also pose problems for exhibitions about childhood. As Pascoe reminds us $(2010,1153)$, 'oral histories concerning childhood are 
always filtered through the haze of nostalgia'. The giant books section of 'Chapters in Childhood' demonstrated that nostalgia for childhood can become compounded by migration and the retelling of stories of 'home'. The most fruitful approaches to recording and displaying toys, along with memories of migration, have been those where a shared historical or geographically-bound experience unites the subjects. In 'On Their Own', child migration schemes provided the historicised structure within which different life stories could be told. And in 'Childhood Memories of Migration' it was common memories of migrant hostels that contextualised the different experiences and belongings of those who had once lived in them. Exhibitions that have located children's toys and adult's memories within the playground, the classroom, the home and out-of-bounds places of exploration, have revealed more about children's changing experiences of migrating to Australia, and, as we have seen, some have also been able to connect those experiences to children currently confined within Australia's immigration detention centres. These findings have implications for the exhibition of toys in museums more broadly - for a display to work, it is the where, as well as the who, what, and when, that can elevate a plaything from an ornament to an object over which a child exerts their agency. And when that object finds its way to a museum through a child-now-grown, it is the memories of the adult who passes it on that must frame its presentation.

\section{References}

Anderson, M. 2011. Museums, history and the creation of memory: $1970-2008$, in Griffin

D. and Paroissien, L., Understanding Museums: Australian Museums and Museology.

National Museum of Australia, published online at http://nma.gov.au/research/understandingmuseums/index.html.

Australian National Maritime Museum and National Museums Liverpool. 2010. 'Pamela

Smedley: Longing for family', On Their Own website, published online at http://otoweb.cloudapp.net/new-lands-new-lives/schemes/pamela-smedley.html

Australian Parliament. 2001. Lost innocents: righting the record: report on child migration. Canberra: Senate Community Affairs References Committee Secretariat, 2001.

Bean, P. and Melville, J. Lost children of the empire. London and Sydney: Unwin Hyman, 1989. 
Brookshaw, S. (nee Roberts). 2006. Minor concerns: representations of children and childhood in British museums. museum and society 4/3, 152-165.

Burrell, K. 2008. Materialising the border: Spaces of mobility and material culture in migration from post-socialist Poland. Mobilities 3/3, 353-373.

Clark, A. 2013. The history wars, pp. 151-166 in Clark, A., and Ashton, P. Australian History Now. Sydney: NewSouth Publishing.

Darian-Smith, K. 2013.Children, colonialism and commemoration, pp.159-174 in DarianSmith, K. and Pascoe. C. (eds.), Children, Childhood and Cultural Heritage. Oxford \& New York: Routledge.

Davey, G.B., Darian-Smith, K. and Pascoe, C. 2013. Playlore as cultural heritage: Traditions and change in Australian children's play, pp. 40-54 in Darian-Smith, K. and Pascoe. C. (eds.), Children, Childhood and Cultural Heritage. Oxford \& New York: Routledge.

Davison, G. and Webber, K. (eds.). 2005. Yesterday's Tomorrows: The Powerhouse Museum and its Precursors, 1880 - 2005. Sydney: Powerhouse Publishing and UNSW Press.

Dunn, M. 2010. Villawood detention centre. Sydney: Dictionary of Sydney, http://dictionaryofsydney.org/entry/villawood_detention_centre.

Economou, N. 2007.Measuring social cohesion in a diverse society, pp. 33-44 in Jupp, J. and Nieuwenhuysen, J., with Dawson, E. Social Cohesion in Australia. Cambridge: Cambridge University Press.

Goodnow, K. 2008. Museums, the media and refugees: stories of crisis, control and compassion. New York: Berghahn Books.

Great Britain, House of Commons. 1998. The welfare of former British child migrants, Select Committee on Health, Third Report. London: The Stationary Office.

Griffin, J. 2011. The museum education mix: students, teachers and museum educators, in Griffin D. and Paroissien, L., Understanding Museums: Australian Museums and Museology. National Museum of Australia, published online at http://nma.gov.au/research/understandingmuseums/index.html. 
Henrich, E. 2013.Museums, history and migration in Australia. History Compass 11/10, 783800

Henrich, E. 2012.Whose Stories are we Telling? Exhibitions of Migration History in Australian Museums, 1984 - 2001. Unpublished Ph.D. thesis, University of New South Wales.

Henrich, E. 2011. Suitcases and Stories: Objects of Migration in Museum Exhibitions. International Journal of the Inclusive Museum 3/4, 71-82

Jones, K. 1999. Producing Tears, Fears and Cheers: Migration to Australia, 1788-1998. Paper presented to the Museums Australia Conference, Albury, May 1999.

http://www.collectionsaustralia.net/sector_info_item/61

Lopez, Mark. 2000. The origins of multiculturalism in Australian politics 1945-1975.

Carlton, Vic.: Melbourne University Press.

McFadzean, M., Gillespie, R., McLean, R. and Churchward, M. 1998.Immigration Museum: Complete Set of Final Text, binder held at Museum Victoria.

McShane, I. 2001. Challenging or conventional? Migration history in Australian museums, pp. 122-133 in McIntyre, D. and Wehner, K. (eds.). Negotiating histories: national museums: conference proceedings. Canberra: National Museum of Australia.

Migration Museum SA. 1987. Temporary Exhibitions Internal Working File.

National Museum of Australia. 2000. Horizons Exhibition Text, binder 2/2, available at the National Museum of Australia Research Library, Canberra.

Pascoe, C. 2013. Putting away the things of childhood: Museum representations of children's cultural heritage, pp.209-221 in Darian-Smith, K. and Pascoe.C. (eds.), Children, Childhood and Cultural Heritage. Oxford \& New York: Routledge.

Pascoe, C. 2010. The History of Children in Australia: An Interdisciplinary Historiography. History Compass 8/10, 1142-1164.

Pickering, S. 2001. Common Sense and Original Deviancy: News Discourses and Asylum Seekers in Australia. Journal of Refugee Studies 14/2, 169-186. 
Powerhouse Museum Archives.2004. Childhood Memories of Migration Exhibition Text, File F/03/671.

Rasmussen, C., with 46 contributors. 2001. A Museum for the People: a History of Museum

Victoria and its Predecessors, 1854 - 2000. Carlton, Vic.: Scribe Publications.

Richards, E. 2008.Destination Australia: Migration to Australia Since 1901. Sydney: UNSW Press.

Sleight, S. 2013. 'Let Children be Children': The Place of Child Workers in Museum

Exhibitions and Landscapes of the Past, pp. 126-43 in Darian-Smith, K. and Pascoe. C. (eds.),

Children, Childhood and Cultural Heritage. Oxford \& New York: Routledge.

Szekeres, V. 1987. The use of oral history in museum displays. Oral History Association of Australia Journal 9, 112-116.

Szekeres, V. 2009. Interview by Eureka Henrich, Adelaide, Australia.

Tao, Kim. 2014. Apologies, anniversaries and histories. Australian National Maritime Museum blog. http://anmm.wordpress.com/2014/02/24/apologies-anniversaries-and-hiddenhistories/\#more-12824

Trepa, H. 1997. The Real Thing?: Pennington Hostel Recreation at the National Maritime Museum. Public History Review 6, 164-175.

Trinca, M. 2013. History in museums, pp. 136-150 in Clark, A., and Ashton, P. Australian History Now. Sydney: NewSouth Publishing.

\footnotetext{
${ }^{1}$ I have refrained from defining 'childhood' in this article, as museum exhibitions about migration have included children of all ages, including adolescents.

${ }^{2}$ The best known example draws on the collections of the British Museum: McGregor, N. 2010. A History of the World in 100 Objects, London: Allen Lane. For an excellent Australian example see Thompson, S. 2012. Objects Through Time: 100 Objects that Define Modern Australia, Sydney, NSW: NSW Migration Heritage Centre.

${ }^{3}$ Playlore is an alternative term for children's folklore, and includes 'the games, songs, rhymes and rituals that circulate amongst children'. Darian-Smith and Pascoe, 'Mapping the field' in Children, Childhood and Cultural Heritage, p. 10 .

${ }^{4}$ The Children's Library is now subsumed within the Children's Literature Research Collection, comprising over 65,000 items including comics, children's newspapers and magazines, toys and greeting cards. See http://www.slsa.sa.gov.au/clrc/ Accessed 10 May 2014.

${ }^{5}$ The term 'dago' comes from America where is was used as a derogatory term for Spanish people. In Australia it was applied to different non-British people, but particularly those of Mediterranean background.

${ }^{6}$ The NSW Migration Heritage Centre and a plethora of smaller community museums were also exhibiting the stories of migrants. See Henrich, E. 2013. 'Museums, history and migration in Australia'.
} 